\title{
A SUPPLEMENT OF PATHOLOGICAL PHYLOLICAL PHYSIOLOGY \\ ON THE SO-CALLED LABYRINTHINE DEAFNESS
}

By

T. HAYASHI

From the Department of Oto-Rhino-Laryngology School of Medicine, Nagoya Uuiversity

(Director: Prof. S. Goto)

In order to study the origin of labyrinthine deafness, 70 patients with labyrinthine deafness were examined for their auditory function and autonomic nerve function. The results obtained were as follows :

The causes of labyrinthine deafness were classified. Those due to hereditary factors were 5 , Ménière's disease 5, middle ear disease 4, Presbycusis 4, Occupational deafness 3, syphilis 3, Typ̣us 2, Epidemic cerebrospinal meningitis 1, Pregnancy 1 and Unknown cause 39.

The function of antonomic nervous system were examined by using adrergic and cholinergic drug and classified as follows: Unbalance of antonomic nervous system 1, Hyperactivity of autonomic nervous system 11, Sympathicotonia 10, Unbalance of parasympathetic nervous system 7 , Vagotonia 22, Hypoactivity of autonomic nervous system 7, Normal 12.

The condition of vagotonia was often found in patients with hearing impairment by unknown etiology, especially in late stage of the disease. Generally, at the begining of hearing impairment and Ménière's disease, the patients have a tendency of sympathicotonia.

In patients with hypoactivity of vestibular function which was diagnosed by rotatory nystagmus test, condition of vagotonia, vagotonic unbalance and hypoactivity of autonomic nervous system was noticed,

Vestibular dysfunction was not always marked in labyrinthine deafness. Hearing impairment was severe in degree in cases with vestibular dysfunction.

In conclusion, sympathicotonic condition seems to manifest itself in early stage of labyrinthine deafness, while it shifts vagotonic condition in later stage.

\section{所謂内耳性難聴の病生理補遺}

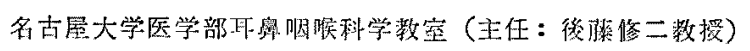

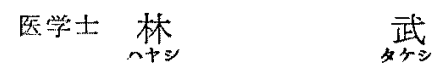
第了章 緒言
目次
第2 章研究材料及び研究方法
1) 研究材料
2) 研究方法
a) 聴器機能検査
b) 白律神経系拾查

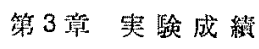
1) 聜力像飞就いて
2）前庭機能に就いて
3) 自律神経系の状態に就いて
4) 璃力像之前庭機能々の関俰
5) 聴力像之自律神経系の状態乞の関係
6)、前庭機能と自律神経系の状熊との䦭俰 


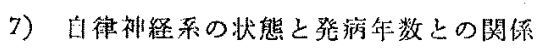

8）年令々自律利経系の状態上の関俰

9）難倰の原因と自律袖経䒺の状態との関倸

10) 原因不明なるもの」内聑性踓聴に就いて

11） $x=$ ニール氏病に就いて

第 4 毫 総括並に考按

籍 5 章 結諭

\section{第 1 章 緒 䨐}

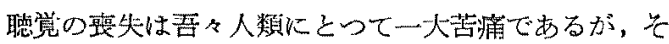
の原因が外耳又は中耳にむる埸合は乞の沿療もむる程度 可能であるが，内耳及びをれより中枢に原因を有する所 謂内耳性難㯖者に扎いては原因探求子困難老極め良つて 治撩も難しく全く不可能の場合も多くある。

しかして内耳性難㯖の原因に就いては実駼的に色々の ものが挙げられているが，実際臨床上に果してそれが原 因であるかは必ずしも確言できない，臨床上には遺伝的 関係を明かにしたものとかメニエール氏病等は研究の対 穷となつているが，実際上には原因不明なるものが多 い.

メニェール氏病に就いては古来幾多の学者に上り矿”

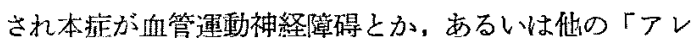
ルギー」性䛈患に合併して起る内耳「アレルギー」等に より内耳に異常な充血忍は頚血をきたしるいては内耳組 織に退行性变化をきたすのではないか即ち自律神経利の 異常が先の原因之考光られ，且又迷路と自符神経系とは 密接な関保があるとも多数埌告されている。先こで他 の一般の内耳性難聴において子自律神経系口失調が閶係 あるのではないかと考え及ら゙のは当然であるが，この程 の研究は今までにない。

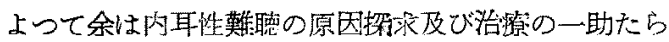
んと思い，本学外来患者中で所謂内耳性難聴之考党られ る患者の聴器機能及び自律神経系を検查し聊が和見を得 たのでこっにそれを発表し諸賢の御批判を仰んとする次 第である。

\section{第2 章 研究材料及び研究方法}

(1) 研究枌料

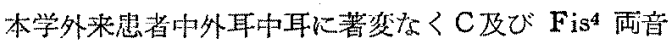
叉江よる聴力検查で内耳性難㯖之思われるもの70例を゙ 研究対象として選んだ，

これ等の患者の年令は第 1 表沉示す如く文難㯖発現の 原因と考えられる奖患を分類するに第 2 表に示寸通りで ある. 原因不明で進行性にくる所謂内耳性難聴が 39 例 (56\%) で最も多く，次で遗伝性，メニエール氏病が各

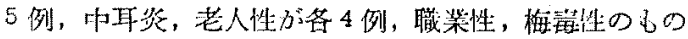

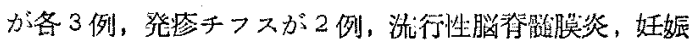
が各!例で方る。
第 1 表 年令及性别

\begin{tabular}{|c|c|c|c|}
\hline 94 性別 & 8 & 9 & 計 \\
\hline $10-20$ & 11 & 4 & 15 \\
\hline $21-30$ & 14 & 13 & 27 \\
\hline $31-40$ & 11 & 3 & 14 \\
\hline $41-50$ & 3 & 5 & 8 \\
\hline $51-60$ & 3 & & 3 \\
\hline 61 以上 & 3 & & 3 \\
\hline 計 & 45 & 25 & 70 \\
\hline
\end{tabular}

第 2 表 原因筷㦝

\begin{tabular}{|c|c|}
\hline 病 & 㤡 \\
\hline 造 伝 性 & 5 \\
\hline$x=$ エール氏病 & 5 \\
\hline 中 耳 炎 & 4 \\
\hline 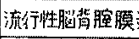 & 1 \\
\hline 発疹チブス & 2 \\
\hline 官 能 性 & 3 \\
\hline 原恩不明脠行性 & 39 \\
\hline 践 桠 性 & 3 \\
\hline 老人 & 4 \\
\hline 梅 & 3 \\
\hline 妵 & 1 \\
\hline 計 & 70 \\
\hline
\end{tabular}

(2) 矿究方法

a) 聴器機能検查

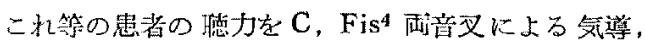
C 音叉によるWeber 氏検查, Rinne 氏検查及び $\mathrm{S}$ chw

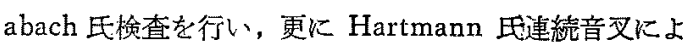
つて検查して聴力 $30 \%$ 以下を高度，30〜60\%を中等度， 60〜80\%を軽度難聴とした。

前庭機能倹查は迴抎及び温度刺战に上り眼球振盪に上 つた。即ち 15 秒，10廻転の刺战を字元た後の眼震を検 查し，之の持続封間 20 秒 40 秒 (承均 25 秒) を正常 とし，15 秒以下，40 秒以上を夫々㙨能但下及び機能九 進とした。温度性眼震仕 $27^{\circ} \mathrm{C}$ 冷水を羽い潜代时閒 25 秒 (20 秒 30 秒), 持続時間 90 秒 120 秒を正常とし， $300 \mathrm{cc}$ 用いてな招腿震の発現しない場合は更に $17^{\circ} \mathrm{C}$ の 冷水を用いた。

(b) 自律神経系検查

自律神経系の検查は自律神経琵注射火よつた。即ち $0.1 \%$ 坮化アト゚レナリン，0.1\%硫酸アトロピン. $1 \%$ 塩 酸ピロカルピンの皮下注射後一㭙間の变化を次の基準に よつて判定した.

アドレナリンに対する 反応では（1）血圧上昇 30 粍 以上，(口) 脈膊增加 20 30 以上, (N) 副症状 (一般

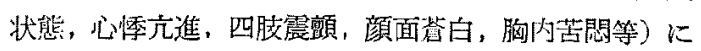
分占，三变化共陽性を(H)，二变化陽性を(H)，一变 化のみ陽性を（十）とした。

アトロピンに対する反心では（イ）脈膊增加 20〜30以 


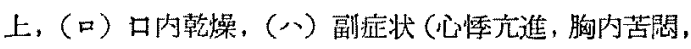
四抆震㛲) の三つに分らアドレナリント同様に判定し た。

ピロカルピンに﨎する反庆では（亿）流涎75cc 以上，

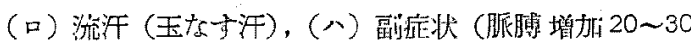

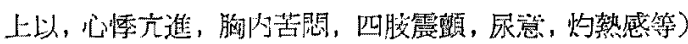
に分らアドレナリンと问粎に判定した。

しかして自街神経系の状惩を上田氏の分類によって次 の如く分類した。

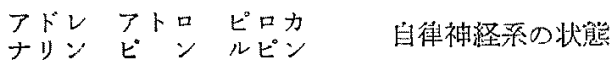

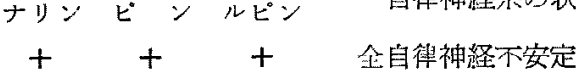

$$
\begin{aligned}
& +\quad+\quad-\quad \text { 副艾感神経緊張但下K }
\end{aligned}
$$

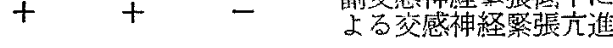

$$
\begin{aligned}
& +\quad-\quad-\quad \text { 资感神経祭張元進 } \\
& -+\quad+\quad \text { 副交感神経不安定 } \\
& \text { - } \quad-\quad+\quad \text { 副效感神経祭張元進 } \\
& \text { - + - 全自律神経䍆張低下 } \\
& \text { - - - IE 常 }
\end{aligned}
$$

\section{第 3 章 实験成績}

(1) 联犯像に就いて

ハルトマン氏連続音攴による聴力像において左右同程度 に聴力低下したもの38 例で，一側が佌側より高度に聴 力低下したるの32 例であるが，㡳側共に亮度に低下し たもの17 例, 中等度低下したもの13 例, 軽度に低下し たもの8例であり，左右非対称性の32例ではその程度

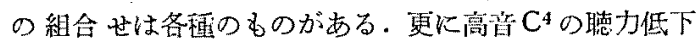

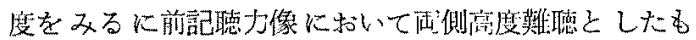

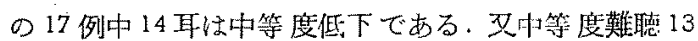
例中C 高度に低下したもの8耳，中等度低下10耳， 軽度低下 8 耳であり，軽度難㯖 8 例中 4 亮度低下 4 耳， 撃度12耳である，応右非対称性のものでは商音の及刘 称性のもの8例である.しかしてC醇度に低下したる の24耳，中等度低下したもの19耳，軽度に低下したも の路る。

(2) 前庭舆能に就いて

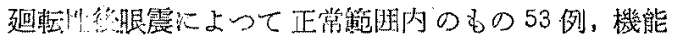
て進のもの3例，機能低下のもの14例ですり，温度性

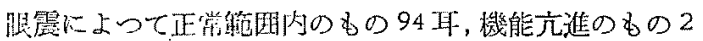
耳，峨能低下のもの44耳である。しかして盂耺性刺㦸

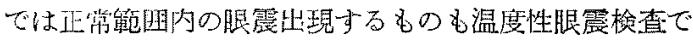

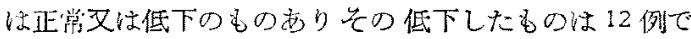
まをが, この逆の舟のは大以。
(3) 自律神絓系の状態に就いて

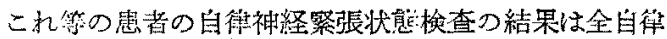
神経不安定 1 例 $(1 \%)$, 全目律神経緊莶六進 11 例 (16

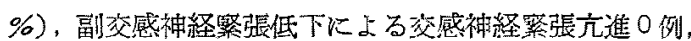

\begin{tabular}{|c|c|c|c|}
\hline & $(-)$ & $(+)$ & $(H)$ \\
\hline アドレナリン検查 & 45 & 21 & 4 \\
\hline アトロビン检查 & 55 & 15 & 0 \\
\hline ピロカルピン检榃 & 27 & 35 & 8 \\
\hline
\end{tabular}

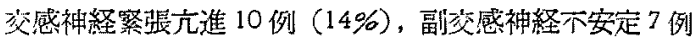

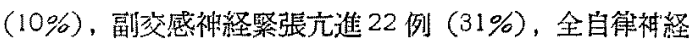

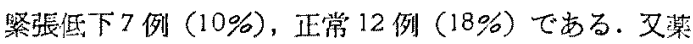
効的自得神経検査の絬果性次の如くである。

な补以下表中に示す自街神経系の状態をアドレナり ン、アトロピン・ピロカルピンの順に配列し (+) (-) の記号をるつて表す 例光ば自律神経不安定 $(+++)$,

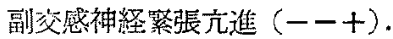

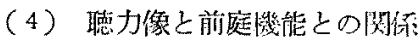

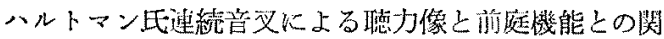
係を多るに迴鞋性刺戟による换查で前庭機能低下したし

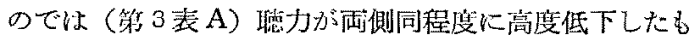
の3例，一側が他側上り強く低下したもの11例である. 温度性刺㦸による検椬で前庭嘰能低下乙たものでは（第 3表B) 聴力障碍高度の6の32耳 $(41 \%)$, 中等度の6 の9耳 $(24 \%)$, 軽度のもの3耳 (14\%) であつて前趜 楼能低下したものに聴力障碍高度のものが多い。

第3 表 ハルトマン比速続省斈による聴力像

\begin{tabular}{|c|c|c|c|c|}
\hline 僡力 & 正常 & 几造 & 但下 & 誩 \\
\hline 対高 & 13 & 7 & 3 & 17 \\
\hline 中 & 12 & 1 & 0 & 13 \\
\hline 程 睤圣 & 7 & 1. & 0 & 8 \\
\hline 非对稱 & 21 & 0 & 11 & 32 \\
\hline 計 & 53 & 3 & 14 & 70 \\
\hline
\end{tabular}
A. 迴轻性制献による

\begin{tabular}{|c|c|c|c|c|}
\hline 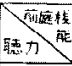 & 正常 & 克進 & 但下 & 計 \\
\hline 高 度 & 46 & 0 & 32 & 78 \\
\hline 中等度 & 28 & 0 & 9 & 37 \\
\hline 軽 度 & 16 & 2 & 3 & 21 \\
\hline 正 常 & 4 & 0 & 0 & 4 \\
\hline 計 & 94 & 2 & 44 & 140 \\
\hline
\end{tabular}
B. 温度性制戟による 解庭機能 前宿機能

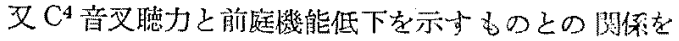

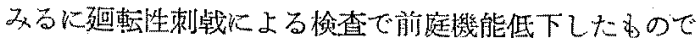

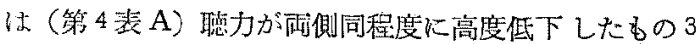
例，一側が他側より強く低下したもの11例である。温 度性刺战による検查で前庭憿能低下 Lたものでは（第 4 表 B) 聴力障碍富度のもの23耳 (41\%6) 中等度のbの14 耳 (32\%) 軖度のもの5耳 (20\%) 正常のもの4耳 (23

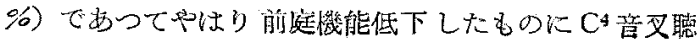


力の高度但下したものが多い。

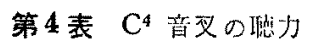

A. 迴枟性刺战に上る 前庭機能

\begin{tabular}{|c|c|c|c|c|c|}
\hline \multicolumn{2}{|c|}{ 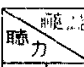 } & \multirow{2}{*}{$\begin{array}{l}\text { 正常 } \\
10\end{array}$} & \multirow{2}{*}{$\frac{\text { 几堡 }}{\prime}$} & \multirow{2}{*}{$\frac{\text { 低下 }}{3}$} & \multirow{2}{*}{$\frac{1}{14}$} \\
\hline \multirow[t]{3}{*}{ 对 } & 高 & & & & \\
\hline & $\phi$ & 9 & 7 & 0 & 10 \\
\hline & 䡋 & 5 & $f$ & 0 & 6 \\
\hline 秧 & 正 & 3 & 0 & 0 & 3 \\
\hline \multicolumn{2}{|c|}{ 非対程 } & $\overline{21}$ & 0 & 11 & 32 \\
\hline \multicolumn{2}{|c|}{ 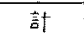 } & 5 & 3 & 14 & 70 \\
\hline
\end{tabular}

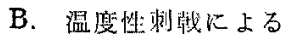
前庭機能

\begin{tabular}{|c|c|c|c|c|}
\hline 前超笪 & 正常 & 䒕连 & 低下 & 部 \\
\hline 高度 & 33 & 0 & 23 & 56 \\
\hline 中等度 & 29 & 0 & 14 & 43 \\
\hline 軽 度 & 17 & 2 & 5 & 24 \\
\hline 正 窝 & 13 & 0 & 4 & 17 \\
\hline 訫 & 94 & 2 & 44 & 140 \\
\hline
\end{tabular}

（5）㤵力自律神経系の状態との関俰

悖力と自律神経系の状態との関倸は第 5 ，第6 表に示

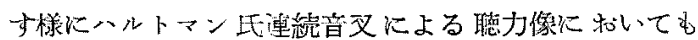

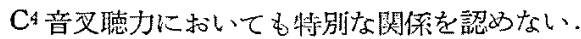

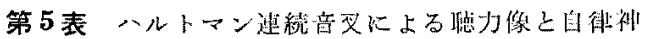
経の炏態との閶倸

\begin{tabular}{|c|c|c|c|c|c|c|c|c|c|c|}
\hline \multicolumn{2}{|c|}{ 职力 } & $1+t$ & $f-1$ & $t+-$ & $t--$ & -11 & -1 & -1 & $\ldots$ & 言十 \\
\hline \multirow[t]{2}{*}{ 对 } & 高度 & & 2 & & .3 & 3 & 4 & 3 & 2 & 17 \\
\hline & 中等度 & & 2 & & $\dot{I}$ & 1 & 5 & 1 & 3 & 13 \\
\hline 䅺 & 倝度 & & & & 2 & 1 & 4 & & 1 & 8 \\
\hline 非 & 対程 & 1 & 7 & & 4 & 2 & 9 & 3 & 6 & 32 \\
\hline & 計 & $\bar{J}$ & 11 & & 10 & 7 & 22 & 7 & 12 & 70 \\
\hline
\end{tabular}

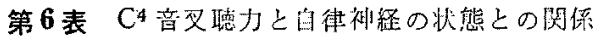

\begin{tabular}{|c|c|c|c|c|c|c|c|c|c|}
\hline \multicolumn{2}{|c|}{ 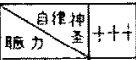 } & & & $t-$ & $-t+$ & --+ & $-t-$ & -- & 計 \\
\hline 对高 & & 2 & & 3 & 1 & 4 & 7 & 3 & 14 \\
\hline 中 & & & & 7 & 2 & 4 & 2 & 1 & 10 \\
\hline 整 & & & & 1 & & 3 & & 2 & 6 \\
\hline 雬 & & & & & & 2 & & & 3 \\
\hline 非対秧 & 1 & 7 & & 5 & 4 & 9 & & 6 & 37 \\
\hline 計 & t & 11 & & 10 & 7 & 22 & 7 & 12 & 70 \\
\hline
\end{tabular}

（6）前庭機能と自律神経系との関係

第 7 表 前庭機能々自律科経の炏熊との圈係

\begin{tabular}{|c|c|c|c|c|c|c|c|c|c|c|}
\hline \multicolumn{2}{|c|}{ 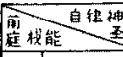 } & $++t$ & $t-t$ & & \multirow{2}{*}{9} & \multirow{2}{*}{$\frac{-+1}{4}$} & \multirow{2}{*}{-1} & \multirow{2}{*}{$\begin{array}{r}-+- \\
4 \\
\end{array}$} & \multirow{2}{*}{\begin{tabular}{|c|} 
\\
\end{tabular}} & \multirow{2}{*}{\begin{tabular}{|l}
$\begin{array}{c}0 \\
53 \\
\end{array}$ \\
\end{tabular}} \\
\hline 正 & 建秐性 & 7 & 10 & & & & & & & \\
\hline 常 & 温度性 & & 15 & & 11 & 7 & 33 & 8 & 18 & 94 \\
\hline え & 这瞈性 & & & & & & 3 & & & 3 \\
\hline 進 & 温度性 & & & & & & 2 & & & 2 \\
\hline 桠 & 巡枟性 & & 1 & & 1 & 3 & 3 & 3 & 3 & 14 \\
\hline$F$ & 温度性 & 2 & 7 & & 9 & 7 & 7 & 6 & 6 & 44 \\
\hline & 姻杜性 & 7 & 11 & & 10 & 7 & 22 & 7 & 12 & 70 \\
\hline & 温度恃 & $?$ & 22 & & 20 & 14 & 44 & 14 & 24 & 140 \\
\hline
\end{tabular}

第7 表に示す上らに前庭機能の正常範困内のものが多 いが異常を示すものでは機能但:下が多い，迴転性後眼震 検查による前庭機能低下のbの〉自律神経系は副资感神

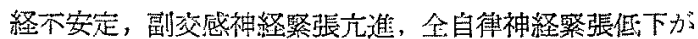
多いが，温度性眼震による尚場合に汒前庭機能低下と自律 神跬系の状態との間に特別の関保怔認められない，

（7）発病年数之自律神経系状態之の関係

第8表に示すように自律神経系の状態が全自律神経不

第 8 表 発病年数と自律䘞経系の状热との閵保

\begin{tabular}{|c|c|c|c|c|c|c|c|c|c|}
\hline 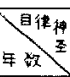 & & $-t$ & ++- & +-- & -++ & --+ & -+- & $\cdots$ & 計 \\
\hline 1 & & 4 & & 4 & & 3 & 2 & 1 & 14 \\
\hline 2 & & 2 & & 1 & 1 & 2 & 1 & 3 & 10 \\
\hline 3 & & & & 1 & & 2 & & 1 & 4 \\
\hline 4 & 1 & 1 & & & & 2 & & & 4 \\
\hline 5 & & & & 1 & I & 1 & $I$ & & 4 \\
\hline 6 & & 1 & & & & 3 & . & 2 & 6 \\
\hline 7 & & & & & & . & 1 & & 1 \\
\hline 8 & & & & & & 1 & & & i \\
\hline 9 & & & & & & & & & \\
\hline 10 & & 1 & & & & 2 & I & 2 & 6 \\
\hline 15 & & 1 & & 1 & 2 & 2 & & 1 & 7 \\
\hline 20 & & & & 2 & 2 & 2 & & 1 & 7 \\
\hline 30 & & 1 & & & 1 & 2 & I & & 5 \\
\hline 40 & & & & & & & & & \\
\hline 50 & & & & & & & & $y$ & 1 \\
\hline 計 & l & $1 /$ & & 10 & 7 & 22 & 7 & 12 & 70 \\
\hline
\end{tabular}

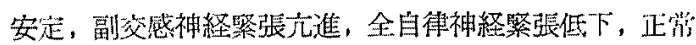
のものは発病種々の年数のもの証められるが，全自律 神経䇣張六進, 交感神経祭張穴進, 副艾感神経不安定の ものは発病年数少いもの及び発病後長年月を経たものに

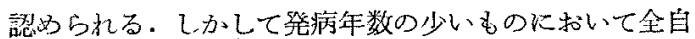
律神経繁張元進の子の及恃交感神経蔡張のものが多く，

第 9 表 年令々自律神経の状態との閔倸

\begin{tabular}{|c|c|c|c|c|c|c|c|}
\hline 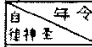 & $10-20$ & $21-30$ & $31-40$ & $4-50$ & $5 i-60$ & $6 r^{3 / 2}$ & 尌 \\
\hline$++t$ & & 1 & & & & & I \\
\hline$+-t$ & 2 & 3 & 3 & 2 & & 1 & 11 \\
\hline++- & & & & & & & \\
\hline+-- & 2 & 5 & 2 & & I & & 10 \\
\hline-++ & 2 & 2 & 2 & 1 & & & 7 \\
\hline--+ & 7 & 8 & 3 & 3 & 7 & & 22 \\
\hline-+- & 1 & 2 & $i$ & 1 & 7 & 1 & 7 \\
\hline--- & 1 & 6 & 2 & 1 & 1 & 1 & 12 \\
\hline 計 & 15 & 27 & 13 & 8 & 4 & 3 & 70 \\
\hline
\end{tabular}


発病年数を経たものは副交感神経緊張充進，同不安定の ものが多い.

(8) 年命と自律神経系との関俰

笛9表において年令と自律神経系の状態上の関保: 又

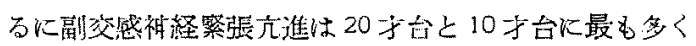
30 于以下と 31 于以上に分けて自律神経系の状態を无る と次に貝与よらになる。

自得神経系の状意 30 无以下 31 年以上

$\begin{array}{lrl}+++ & 1 \text { 例 }(2 \%) & 0 \\ +-- & 5 \text { 例 }(12 \%) & 6 \text { 例 }(21 \%) \\ +-- & 7 \text { 例 }(17 \%) & 3 \text { 例 }(11 \%) \\ -++ & 4 \text { 例 }(10 \%) & 3 \text { 例 }(11 \%) \\ --+ & 15 \text { 例 }(36 \%) & 7 \text { 例 }(25 \%) \\ -+- & 3 \text { 例 }(7 \%) & 4 \text { 例 }(14 \%) \\ --- & 7 \text { 例 }(17 \%) & 5 \text { 例 }(18 \%)\end{array}$

（9）難㯖の原因之自律神経系の状態との間係

難㥁の原因之自律神経系の状態上を表示与百之符 10 表の通りで吉るが，この内原因不明なものとメニエール

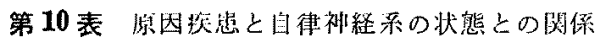

\begin{tabular}{|c|c|c|c|c|c|c|c|c|c|c|c|c|}
\hline 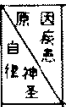 & $\begin{array}{l}\text { 遗 } \\
\text { 伝 } \\
\text { 性 } \\
\end{array}$ & 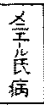 & 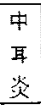 & & 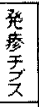 & $\begin{array}{c}\text { 官 } \\
\text { 能 } \\
\text { 性 }\end{array}$ & 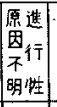 & 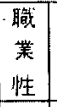 & $\begin{array}{c} \\
\text { 人 } \\
\text { 性 }\end{array}$ & $\begin{array}{l}\text { 梅 } \\
\text { 堛 } \\
\text { 性 } \\
\end{array}$ & $\begin{array}{l}\text { 妵 } \\
\text { 娠 } \\
\end{array}$ & 計 \\
\hline$t+t$ & & 1 & & & & & & & & & & 1 \\
\hline$t-+$ & & 1 & & & 1 & & 8 & & I & & & 11 \\
\hline++- & & & & & & & & & & & & \\
\hline+-- & & 2 & 2 & & 1 & & 4 & 1 & & & & 10 \\
\hline$\overline{-+t}$ & 2 & & & & & & 4 & 1 & & & & 7 \\
\hline$--t$ & 1 & & 2 & & & 1 & 16 & 1 & & $y$ & & 22 \\
\hline+ & 2 & 1 & & & & 1 & 1 & & 1 & $I$ & & 7 \\
\hline$\cdots$ & & & & 1 & & 1 & 6 & & 2 & 1 & 1 & 12 \\
\hline 計 & 5 & 5 & 4 & 1 & 2 & 3 & 39 & 3 & 4 & 3 & 1 & 70 \\
\hline
\end{tabular}

氏病に就いてみると炏のようである。即も原因不明なる 毛の39例に括いては

$\begin{array}{lrr}--+ & 16 & \text { 例 } \\ +-+ & 8 & \text { 例 } \\ -++ & 4 & \text { 例 } \\ --- & 6 & \text { 例 } \\ +-- & 4 & \text { 例 } \\ -+- & 1 & \text { 例 }\end{array}$

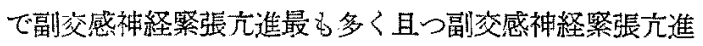
のもの 22 例硼 $73 \%$ に相当与る。

又メニェール氏病 5 例に打いては<smiles>[P+3]</smiles>

$$
\begin{array}{lll}
+-+ & 1 & \text { 例 } \\
+-- & 2 & \text { 例 } \\
-+- & 1 & \text { 例 }
\end{array}
$$

であって交感神経緊張の状態に傾いている。

(10) 原因不鹏の内耳性難聴に就いて

こつに最も間笾となる原因不明の内耳性難㯖心就いて

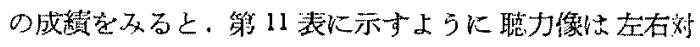
称性のもの20 例, 非刘称性のもの19 例であつて，迴䩪 性刺战による前庭機能検查でその㙨能伿下したものは媤 力像非対称性のものに多く，温度性刺戙による前庭僟能 柃楂でその機能但下したものに聴力媁碍高度のものが多 w.

第 11 表 原因不明沈るものよハルトマン氏連続音 必による惪力像

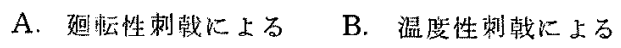

\begin{tabular}{|c|c|c|c|c|}
\hline 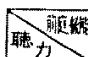 & & 艺谁 & 但下 & 計 \\
\hline 对 [高 & 6 & 1 & I & 8 \\
\hline 中 & 8 & $I$ & 0 & 9 \\
\hline 稱 & 2 & 1 & 0 & 3 \\
\hline 非对稱 & 13 & 0 & 6 & 19 \\
\hline 計 & 29 & 3 & 7 & 39 \\
\hline
\end{tabular}
前庭機能

\begin{tabular}{|c|c|c|c|c|}
\hline 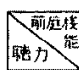 & 正常 & 兑進 & 但 F & 部 \\
\hline 高度 & 25 & 0 & 16 & 41 \\
\hline 中等度 & 20 & 0 & 14 & 24 \\
\hline 軽 度 & 9 & 2 & 0 & 11 \\
\hline 正常 & 2 & 0 & 0 & 2 \\
\hline 計 & 55 & 2 & 20 & 78 \\
\hline
\end{tabular}
前庭機能

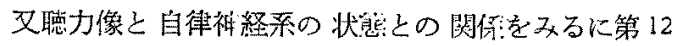

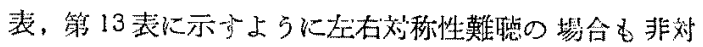

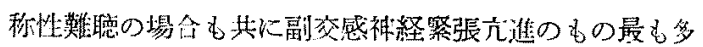

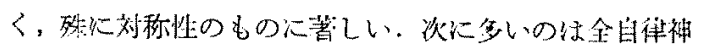
経緊張元進である。

\begin{tabular}{|c|c|c|c|c|c|c|c|c|}
\hline 自律神 & +-+ & t+- & +- &.-+ & $--t$ & -+- & -- & 計 \\
\hline 对高度 & 2 & & & 2 & 3 & & 7 & 8 \\
\hline 中等展 & 2 & & 1 & & 5 & & 7 & 9 \\
\hline 唡軽度 & & & 7 & & 2 & & & 3 \\
\hline 非对相 & 4 & & 2 & 2 & 6 & 1 & 4 & 79 \\
\hline 壾 & 8 & & 4 & 4 & 16 & 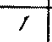 & 6 & 39 \\
\hline
\end{tabular}

第 12 表 原因不明なるものつハルトマン氏速紶音叉 に上る㴧力像と自律神経系の状態との関係

又湔庭機能と自律神経系の状俧 しの関你をみるに第 14 表に示すように方庭機能充進しているものは副交感 神経緊張光進のものつスであつで，前延機能低下してい るものは全自律神経緊張光進, 副交感神経不安定, 副交 感緊張のものである. 


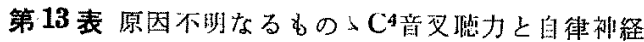
柔の状態上の四保

\begin{tabular}{|c|c|c|c|c|c|c|c|c|c|c|}
\hline \multicolumn{2}{|c|}{ 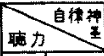 } & $t+t$ & $t-+$ & ++- & +-- & $-t+$ & $-2-+$ & -+- & --- & 計 \\
\hline 対 & 高度 & & 2 & & I & & 2 & & 2 & 7 \\
\hline & 中宗度 & & & & 1 & I & 4 & & & 6 \\
\hline & 輊度 & & & & & & 2 & & & 2 \\
\hline 雬 & 正常 & & 1 & & & & 2 & & & 3 \\
\hline & 扵碃 & & 5 & & 2 & 3 & 6 & 1 & 4 & 21 \\
\hline & \pm+ & & 8 & & 4 & 4 & 16 & 1 & 6 & 39 \\
\hline
\end{tabular}

第14表 原因不明なるもの>前这機能之白律利経系 の将態との關倸

\begin{tabular}{|c|c|c|c|c|c|c|c|c|c|c|}
\hline \multicolumn{2}{|c|}{ 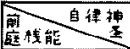 } & \multirow[b]{2}{*}{ 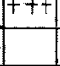 } & \multirow{2}{*}{$\frac{t-t}{7}$} & \multirow{2}{*}{$t+-$} & \multirow{2}{*}{$\mid+--$} & \multirow{2}{*}{$\frac{-++}{2}$} & \multirow{2}{*}{$\frac{-+}{12}$} & \multirow{2}{*}{$\frac{-t-}{1}$} & \multirow{2}{*}{$\frac{--}{3}$} & \multirow{2}{*}{$\frac{\text { 許 }}{29}$} \\
\hline 正 & 迥転性 & & & & & & & & & \\
\hline 常 & 温度性 & & 11 & & 5 & 4 & 28 & 2 & 6 & 56 \\
\hline $\bar{\pi}$ & 尪転性 & & & & & & 3 & & & 3 \\
\hline 進 & 温度性 & & & & & & 2 & & & 2 \\
\hline \multirow{2}{*}{$\begin{array}{l}\text { 低 } \\
\text { 下 }\end{array}$} & 廹転性 & & 1 & & & 2 & 7 & & 3 & 7 \\
\hline & 温度性 & & 5 & & 3 & 4 & 2 & & 6 & 20 \\
\hline \multirow{2}{*}{ 計 } & 迥枟性 & & 8 & & 4 & 4 & 16 & 1 & 6 & 39 \\
\hline & 温度性 & & 16 & & 8 & 8 & 32 & 2 & 12 & 78 \\
\hline
\end{tabular}

第 15 表 原因不明なるもの今発病年数と自律神経系 の状態との関係

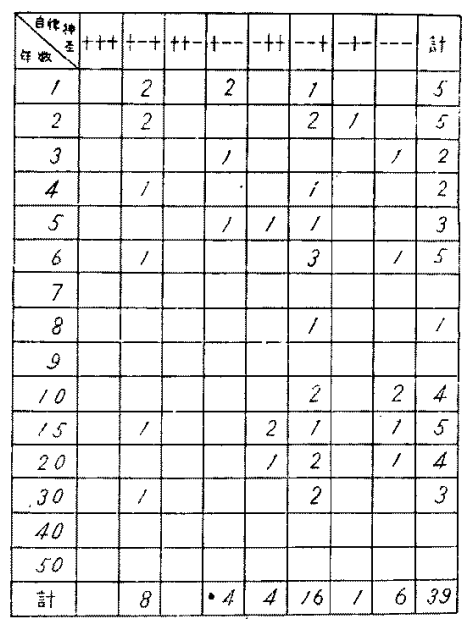

次にこれ等原因不明なるもの〉発病年数と自靾神経系 の状態との関保考素すると第 15 表に示すよ5に全自 律被経緊張无進は発病後 4年以内の女の63\%，5年〜9 年，10年以上のものは夫\& $13 \% ， 25 \%$ であり，交感神 経祭張九進の60は発病後 4 年以内 $75 \%, 5$ 年 9 年は 25\%であり, 副交感神経祭張六進のbのは発病後 4 年以
内 $25 \% ， 5$ 年〜9年 $31 \% ， 10$ 年以上 $44 \%$ である。

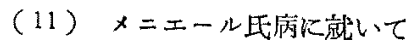

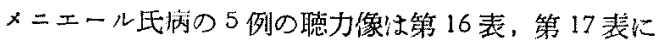
示すように総て非刘称性で亦つて，その前庭嘰能は但下 したもの多く，殊に温度性眼震による前庭㙨能検查では 殆ど低下したものである，しか子媤力障碍の㤝いものに 前庭线能表低下ててている。

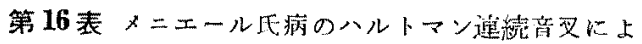
る聴力像

\section{A. 堨枟性刺戟による \\ B. 湿度性刺戟による} 前莛嘰能 前庭機能

\begin{tabular}{|c|c|c|c|c|}
\hline 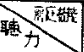 & 正常 & 光進 & 低下 & 柿 \\
\hline 対 & & & & \\
\hline 中 & & & & \\
\hline 程 軽 & & & & \\
\hline 非对稆 & 3 & & 2 & 5 \\
\hline 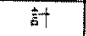 & 3 & & 2 & 5 \\
\hline
\end{tabular}

\begin{tabular}{|c|c|c|c|c|}
\hline 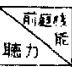 & 正常 & 方望 & 但T & st \\
\hline 高度 & & & 6 & 6 \\
\hline 中等厚 & & & 3 & 3 \\
\hline 軽 度 & & & & \\
\hline 正营 & I & & ' & 1 \\
\hline 計 & 1 & & 9 & 10 \\
\hline
\end{tabular}

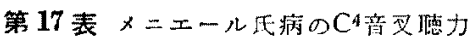
A. 迴転性刺戙による 前庭機能
B. 温度性刺戟による 前庭機能

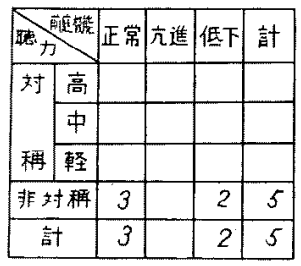

\begin{tabular}{|c|c|c|c|c|}
\hline 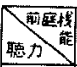 & 正常 & 穴连 & 低下 & 計 \\
\hline 高度 & & & 3 & 3 \\
\hline 中等度 & & & 5 & 5 \\
\hline 軽度 & & & 1 & I \\
\hline 正常 & $I$ & & & 1 \\
\hline 計 & $I$ & & 9 & 10 \\
\hline
\end{tabular}

次にこれ等の症例の自律神経系の状態は $(+++) 1$ 例， (+-+) 1 例，(+-ー) 2 例，(-ー+)1例であ つて交感神経繁張六進儿傾いている. 又前庭機能已自律

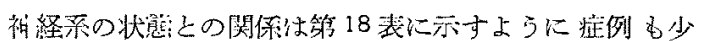

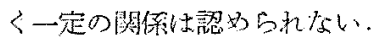

第 18 表 犾態との関倸

\begin{tabular}{|c|c|c|c|c|c|c|c|c|c|c|}
\hline \multicolumn{2}{|c|}{ 要 } & $t+t$ & $t-t$ & ++ & +-- & -++ & --+ & $-+\cdots$ & $-\cdots$ & 部 \\
\hline 正 & 迴枟性 & 1 & 7 & & 7 & & & & & 3 \\
\hline 第 & 賉度性 & & & & t & & & & & 1 \\
\hline$\ddot{\jmath}$ & 迥萿性 & & & & & & & & & \\
\hline 進 & 温度性 & & & & & & & & & \\
\hline 但 & 建檕性 & & & & 1 & & & 1 & & 2 \\
\hline$F$ & 盢度性 & 2 & 2 & & 3 & & & 2 & & 9 \\
\hline \multirow{2}{*}{ 計 } & 奋喠性 & 1 & 1 & & 2 & & & 1 & & 5 \\
\hline & 温度泩 & 2 & 2 & & 4 & & & 2 & & 10 \\
\hline
\end{tabular}




\section{第 4 章 総括並に考按}

所謂内耳性蜼㯖の原因に関しては実験的研究は極めて 多いが，実験的研究のそれと臨床的代診断している難聴 との関係は必ずしも一致するとは限らない，従って臨休

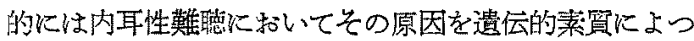
て説明せえとするもの，ビタミン欠乏によつて説明せん としているむの，内分泌暴常によって説明せ九としてい るもの等先の病因は明がされていない，

余はこつに70 例の内耳性難聴患者に就いて艺の䏇器 機能を検すると共仁自律神経系の状態を検したのである が，自律神経系機能検查方法にも色4の基準，方法があ つて一検查法に上つて自律神経機能を判定するのは早計 に失することは当然であるが，所謂内耳性難聴が全くそ の病理不明の今日何等かの手掛りとなるるのと栲えて研 充したのである.そこで余の研索した成績を総括しこれ に洘按を加之てみたい。

70 例中副交感神経祭張 克進のものが 22 例で最も多

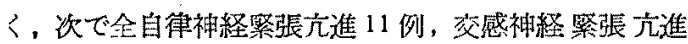
10 例, 副交感神経 不安定及び 全自律神経噤張但下各 7 例，全自律神経不安定 1 例，正常 12 例である.

この自律神経系の状態と年令との関係をみるに副交感 神経繁張㐫進は 30 才以下が 42 例中 15 例で $36 \%$ にあた 门柾めて多いが，31 才以上飞括いても28 例中 7 例で 25\%にみられ壮年者にすかなりみられる，次住自律 神経繁張充進が 30 才以下は 5 例で $12 \% ， 31$ 才以上は 6 例で $21 \%$ ，交感神経緊張光進が 30 子以下は 7 例で17\%， 31 才以上は3 例で $11 \%$ ，副交感神経不安定が 30 于以下 は 4 例で 10\%，31 子以上は 3 例で $11 \%$ ，全自律神経緊 張低下が 30 才以下は3 例で $7 \%, 31$ 才以上は 4 例で $14 \%$ ，全自律神経 不安定が 30 于以下に1例で $2 \%$ ，正 常が 30 才以下は7 例で $17 \% ， 31$ 于以上は 5 例で $18 \%$

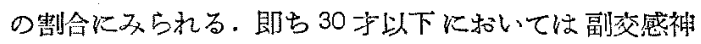
経餐張元進が最も多々, 次で交感神経祭張光進, 全自律 神柽緊張方進, 副资感神経 不安定, 全自律神経祭張低 下，全自律神経不安定の順になる，31 年以上に执いて も副交感神経祭張元進最も多く，次で全自律神経祭張元 進，全自律神経繁張低下，交感神経祭張方進，副交感神 経不安定の順となる。

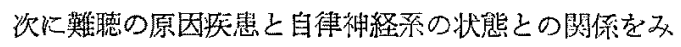
るに副交感神経䇣张六進の内, 原因不明で進行性の所謂

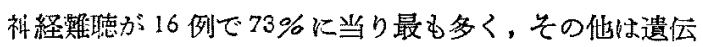
性，中耳炎，官能性，職羍性，梅毒性等である.

即占余任所謂内耳性難㯖患者に恃副交感神経緊張充進

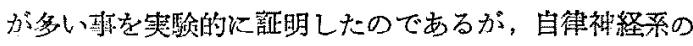
状態が年令によつて差異があり副交感神経䇣張京進が若 い人に多いことは Eppinger, Hess 両氏の既倡えてい る所であり，Czerny 灭び久保田禹氏の実験的飞証明し ている所でもある。しかして若年者に副交感辉経䇣張充 進が多い理由として Eppinger, Hess 雨氏は若年者には 淋巴体資が多いためとしている。余の实験に怙いては 10 30 才゙で 42 例中 15 例（36\%）は副交感神経祭張 光進で若年者に多いが，これ等に淋巴体質をみるめたも のはt大く，且又 31 于以上飞打いてあ 28 例中 7 例 (25\%) に副交感神経緊張元進がみられる点からこの副交髠神経

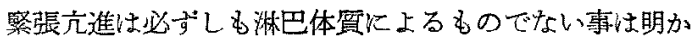
であり，この点に就いては慢性副鼻腔炎患者に副父感神

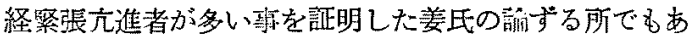

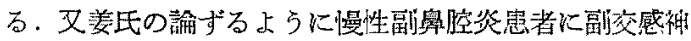
経緊張光進が多い之云ら事から本症を除外しなければな

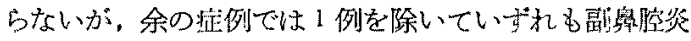

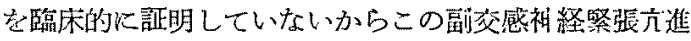

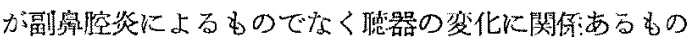
と将点られる。

これに対してメニエール氏病と考えられるすのは交感 神経緊張に傾いていることから原因不明の神経蜼㯖とメ

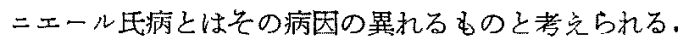

次に自律神経系状態と前庭機能との関係を及るに迴蒜 性後眼震，温度性眼震いずれも正常值を示すものが多く 異常状態を示す中で機能低下が多い，乙かして前莛機

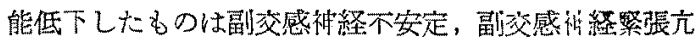
進，全自律神経緊張低下が多い。

前庭器と副交感神経緊張との関保化就いては胃腸運動 を榇能として実験的に研究されている。即ち Byrne は

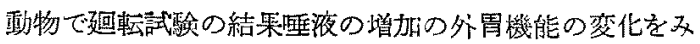

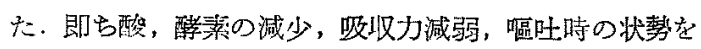

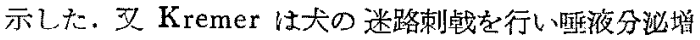
加と胃運動抑制をみ，Spieger u. Démétriades の家鬼 小腸に㧍ける実験で迷路の温熱刺战で振子運動の振幅の 增大, 腸壁緊張の增打を認め,この作用は血圧下降と無 関探江起り遠心性衝野経路としては迷路性血圧下降作用

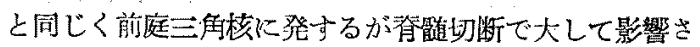
れず送走神経を経て胃腸に達するとなした，又福藤氏も 同様の実跧によつて同じような結果を得ている. 更に逆 に迷走神経を刺戱寸ると迷路性眼震に影響のある事も实 験的江証明されている. 即ち平田氏は植物神経殊湢副 感神経々迷路機能との関係を究明すべく正常家鬼の頸部 


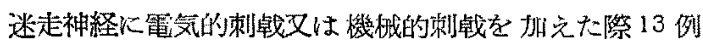
中4 例飞机いて緩急峏成分を有する特発性眼震の出現 するのを諗め Podesta は胃壁刺㦸により特発性眼震が 発現しこれを胃壁の迷路神経の末梢の與藥に上るとし

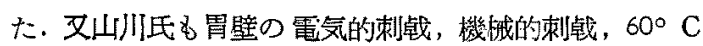
以上の温熱刺战，化学薬品の刺战等により緩急画成分を 有する特発性眼震の起ることを証明している。

前莛機能任下したもの>自律神経系状態化就いては西 端，原田耐氏性中耳真珠尰に原因士る内耳炎の患者の手 術前後の自律神経を検查し，術前了ドレナリン，ピロカ ルピンに対して陰性であつたものが術後二日目で弦陽性 三週間目で弱陽性にフトロピンでは变化なく即ち自律神

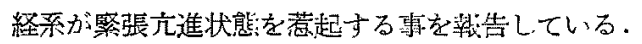

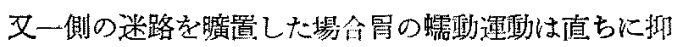
制されるが二時問後に漸く快復し四時間，にて曠置前に厣 り(紫时)，血中淋巴細胞数も輁置後减少し二日目を最

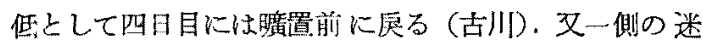
路な䀧置した場合眼零は発現後次筙に增强し同時に悪心

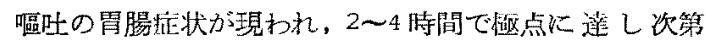
に減弱し 30〜40 時閐で平静となりこれに伴って胃腸症 状も軽減する。

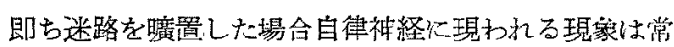
に一過性であって交感神経緊張である.これは丁应メ二 ェール氏病が一過性に症状を藻起するのと一致し且つ余 の研究したよらに交感神経䌎張に傾いていることに一致 している.

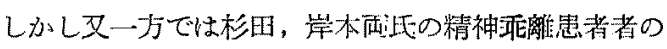
自律神経系の検查炕いてからる患者の白律神経の㗨㖘 状態は各病像によつて一㥞でなく緊張病昏迷期化扔いて

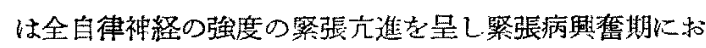

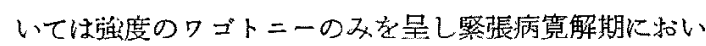

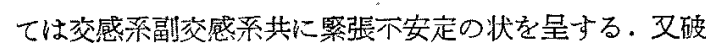

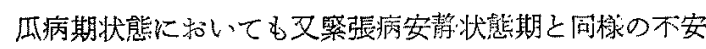

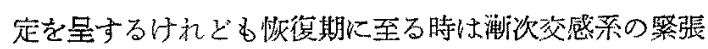
が隇じてワゴトニーに傾き破爪病圆張病共に末期癡果状 態に宿るときは一般にワゴトニ一を呈することを報告し ている.

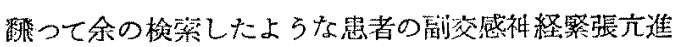
が杉田，岸本雨氏の桷ず劣上らに末期状態を示するので

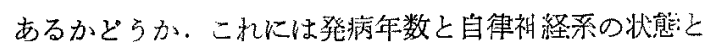
の関係を支るに原因不明な内耳性難媤39 例の副艾感神 経䇣掁六進のものは発病後 4 年以内のもの $25 \%, 5 \sim 9$ 年のもの31\%，10年以上のわの $44 \%$ であって明か澄
病年数の長いもの程到效感神経祭腿亢進のものが多い。 文艾感神経緊張充進のすのは総て発病後年月の少いるの

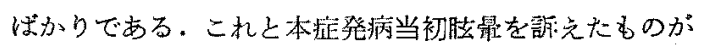
多いこと並にォニエール氏病のるのは交感神経䇣張の傾 向のあること等を考克合せると内耳性難㥁の発病当初は 交感祜経案張の状態が多く年数を経るに従つて副交感神 経緊張光進になるるのと考光られる。

聴力と前庭機能との関係は前庭機能低下したすのでは

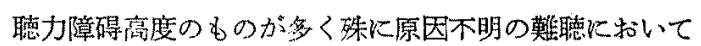
はこの関保著しくォニエール氏病においては殊更にこの 関係は明かである。即方㴔神経の損傷されるにあたつて 前庭神経漳碍された場合においては必主螖牛款神経孔障 碍されていると云らことが管い得る。

\section{第 5 章 結論}

余仕所摆内耳性難聴患者 70 例の畗器㙨能 及び自律神 経柔を険查し次の結論炎得た。

1）原因知急と著えられるものをあげると遣伝性，メ ニェ一几氏病が各5例，中耳炎，老人性難聽が各4例，

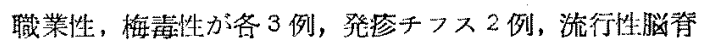

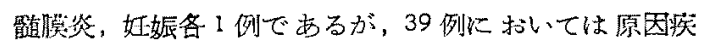
患を見出し得ない所謂原因不明の進行幽難悖である。

2）乙れ等患者の自律神経系の状態を菜効的検查:上 り分類一ると全自律神経不安定 1 例，全自律神経緊張方 焦 11 例, 交感神経緊張立進 10 例, 副交感神経 不安定 7

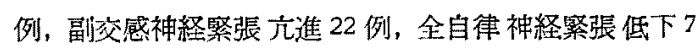
例, 正常 12 例である.

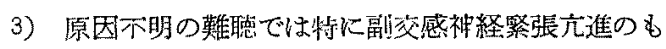
のが多く、殊に発病時日学经心ものに副交感神経絮張九 淮䋾い

しかして発病初期のものに忙资感神経祭張充進の傾向 がある。

4）×ニェール氏病では效感神経祭張九進に傾いてい る.

5）廻転性後腿震検查に上る前庭機能但下のものは副 交感神経繁張立進, 同不安定, 全自律神経繁張低下の のが多い，

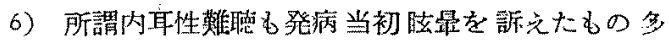
く, 発病年月浅いるのに交感神経紧張亩進の傾向あり.

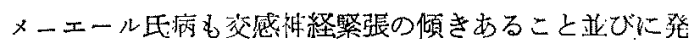

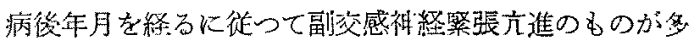
いことから所謂内耳性鹳聴の初期は交感神経繁張穴進の 傾向にあつて次第に副交感神経緊張亩進に変ずるものと 考党られる。 
7) その際蝸牛殼神経つ障碍は必発であるが前庭神経 の障碍は軽度であり前庭機能低下したものは聴力低下が 強い。

\section{文 献}

1) 沖中重雄: 自律神 経 機能の検査法, 医学選書, 昭 22. 2) 沖中重堆：自律神経系々臨床, 炤23。3) 久保田敬吉：腺様增殖症之植物性神経, 耳鬼臨床, 21 巻，457頁. 4) 姜日永：慢性鼠炎及び副鼻腔炎に 関する研究, 京城医寻紀要, 4 巻,545 頁.55) 平田和 夫：迷走神経淑戟による特発性眼球赈盜に就いて, 耳鼻臨床，26 巻，101頁６６）齐藤勤：前庭迷路の晹

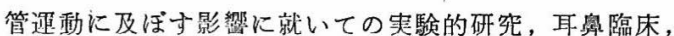

19 巻, 1 面. 7) 山川平作：胃壁刺战の前庭迷路嘰

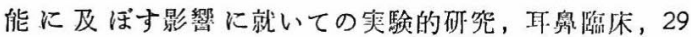

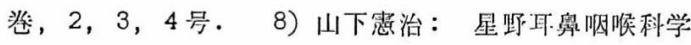

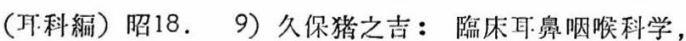
昭15.10) 長谷川高敏：迷路刺戙とその影響, 大日 耳, 48 回総会. 11) 西端繁一一原田輝雄：耳迷路と 内分泌臓器並に自律神経との関係に関する実験的研究,
大日耳, 34 巻, 1152 頁. 12) Eppinger u. Hess: Zur Pathologie d. Vegetative Nervensystem, Zschr. d. Klinisch. Med. Nr. 63 1909. 13) Spiepel u. Démétriades: Beiträge zur Studien des vegetative Nervensystem. Pflüger Arch. f. Physiologie, Bd 199 S. 185,1922, Bd 205, S 328, 1924.14$)$ Podesta: Über die reflektorische Erregburkeit der labyri$n$ ths in seinen gegenseitige Beziehungen zur magen, Zschr, f. Laryngologie Rhinologie u. Otologie. Bd 17, 1928.

本論文を擱筆するに当り終始御䅰篤なる御指導御 騲達及び御校閲を睗りました恩師後藤教授に深く感 謝致します

本諭文要旨は日本耳粤呐喉科学会名占屋地方会第 7 回大会, 104 例会, 105 例会及び日本耳鼻咽喉科学 会第 49 回総会に拈いて発表した.

（原稿到着 $=$ 昭利! 35.5 .6 日）

\section{健保通期用}

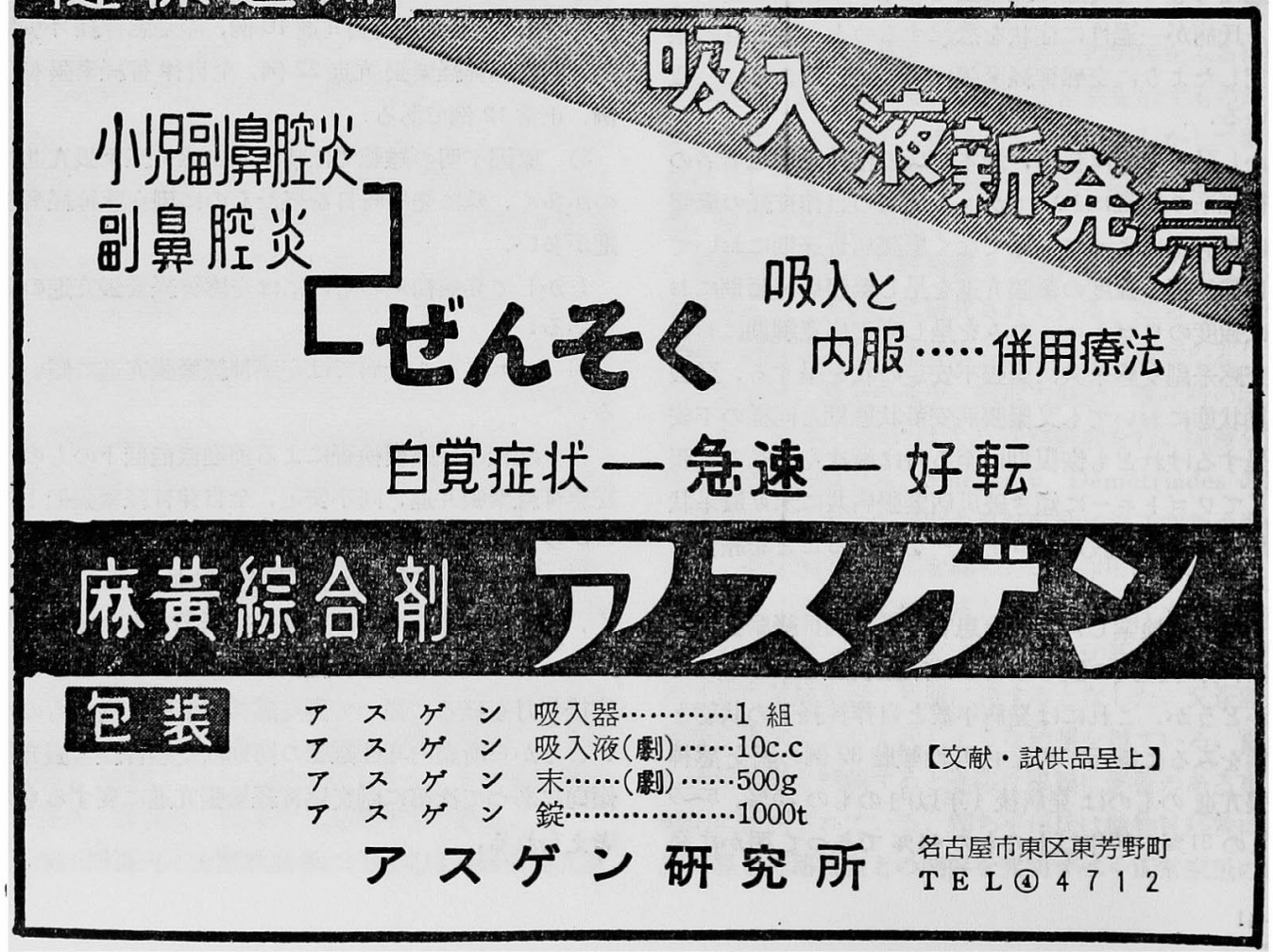

